\title{
Chronic Partial Rupture of the Achilles Tendon - the Flexor Hallucis Longus (FHL) Tendon Transfer: A Report of Two Cases
}

\author{
Mihajlo Mitrović́, Dražen Jelača ${ }^{1}$, Ivana Mitrović ${ }^{2}$ \\ ${ }^{1}$ General Hospital Pančevo, Pančevo, Serbia \\ ${ }^{2}$ City Institute for Emergency Medical Aid Belgrade, Belgrade, Serbia
}

SUMMARY

Achilles tendon injuries most commonly occur in athletes, but also in the middle-aged population practicing recreational sports. The aetiology of injury and disease of the Achilles tendon has not been completely clarified. While acute injury can be attributed to trauma, research showed that a chronic degenerative process is present in most ruptures. While there are still a lot of dilemmas when it comes to treating acute rupture, chronic rupture and disease are predominantly treated operatively. Many operative procedures can be used when treating chronic Achilles tendon diseases, such as excision of degenerative changes and tendon decompression, reconstruction using fascia lata and VY plastics, tendon transfer (Flexor Hallucis Longus - FHL, Flexor Digitorum Longus - FDL, Peroneus Brevis - PB) and allograft and synthetic graft reconstruction. The objective of the paper was to present the results of treating chronic partial Achilles tendon rupture by scar excision and FHL tendon transposition. The patients were one professional and one recreational athlete, both of whom were treated nonoperatively for a long time. They were both tested using AOFAS and ATRS tests preoperatively and postoperatively. The results showed a significant improvement of function and both patients were able to return to their usual activities. Postoperative results of AOFAS and ATRS tests were almost identical to the result on the uninjured leg. Our little series, as well as a lot of research performed by other authors, shows that an FHL tendon transposition is a safe and efficient method in treating diseases and injuries of the Achilles tendon.

Key words: Achilles tendon, FHL tendon, transposition, partial rupture

Corresponding author:

Mihajlo Mitrović

e-mail: drmihajlo@gmail.co 


\section{INTRODUCTION}

The Achilles tendon is the largest and strongest tendon of the human body, but it is also the tendon most commonly injured and prone to diseases (1). In the last 20 years, there has been a noticeable increase in diseases and injuries of the Achilles tendon, mainly due to the rising number of middle-aged people practicing recreational sports (2). While acute rupture and disease of the Achilles tendon are most commonly found in professional athletes, chronic partial ruptures and tendinosis are very common within the middle-aged population (3).

As far back in history as Hippocrates, the importance of diagnosis and treatment of Achilles tendon injury has been accentuated, as they commonly cause disability and even death. The importance of this type of injury is recognized in the works of Amboise Paré, who described the Achilles tendon injury and suggested his type of treatment in 1575. The first Achilles tendon surgery was described in 1888 by Polaillon, a French doctor, but some data indicate that it was performed by Arabian doctors as early as the $10^{\text {th }}$ century (4).

The etiology of injury and disease of the Achilles tendon has not been completely clarified (5). While acute injury can be attributed to trauma, a great body of research points out that a chronic degenerative process underlies most ruptures. It is not completely clear why degenerative changes occur and they can be caused by many intrinsic and extrinsic factors, which is the main cause of disagreement regarding the type of therapy (6). When dealing with an acute injury, there are a lot of dilemmas regarding the benefits of operative vs nonoperative treatment, but when it comes to chronic diseases or injuries of the Achilles tendon, they are predominantly treated surgically (7). Many operative procedures can be used when treating chronic Achilles tendon diseases, such as excision of degenerative changes and tendon decompression, reconstruction using fascia lata and VY plastics, tendon transfer (FHL, FDL, PB) and allograft and synthetic graft reconstruction $(8,9)$.

Two cases of chronic partial Achilles tendon rupture treated surgically by excising the degenerated part of the tendon and strengthening it with FHL tendon transfer will be presented. The results of the treatment were evaluated using the standardized AOFAS ankle-hind foot scale (American Orthopedic Foot Ankle Society) test and the ATRS (Achilles
Tendon Total Rupture Score) test (10). The loss of big toe flexion as a result of transferring the FHL tendon was also analyzed.

\section{FIRST CASE REPORT}

The first patient was a 36-year-old male complaining of incessant pain and oedema at the site of the left Achilles tendon insertion, as well as muscle weakness in the left foot. He had injured himself 15 months earlier as a result of a jump during a handball game. He was an active athlete, a professional handball player. Apart from the physical examination, an ultrasound examination of the Achilles tendon was required, which revealed a partial rupture of the distal segment of the tendon. The first round of treatment included nonoperative treatment: plaster immobilization and several rounds of physical therapy. The results were not satisfactory, as the patient was still unable to play handball or indulge in any kind of physical activity. His complaints were present every day, he felt morning stiffness in the tendon, and pain and discomfort as a result of any and all types of exertion, which would force him to stop with activities. He also submitted an MRI of the Achilles tendon, which confirmed the presence of the partial rupture at the level of the distal inser-

Figure 1. A:Hockey stick incision

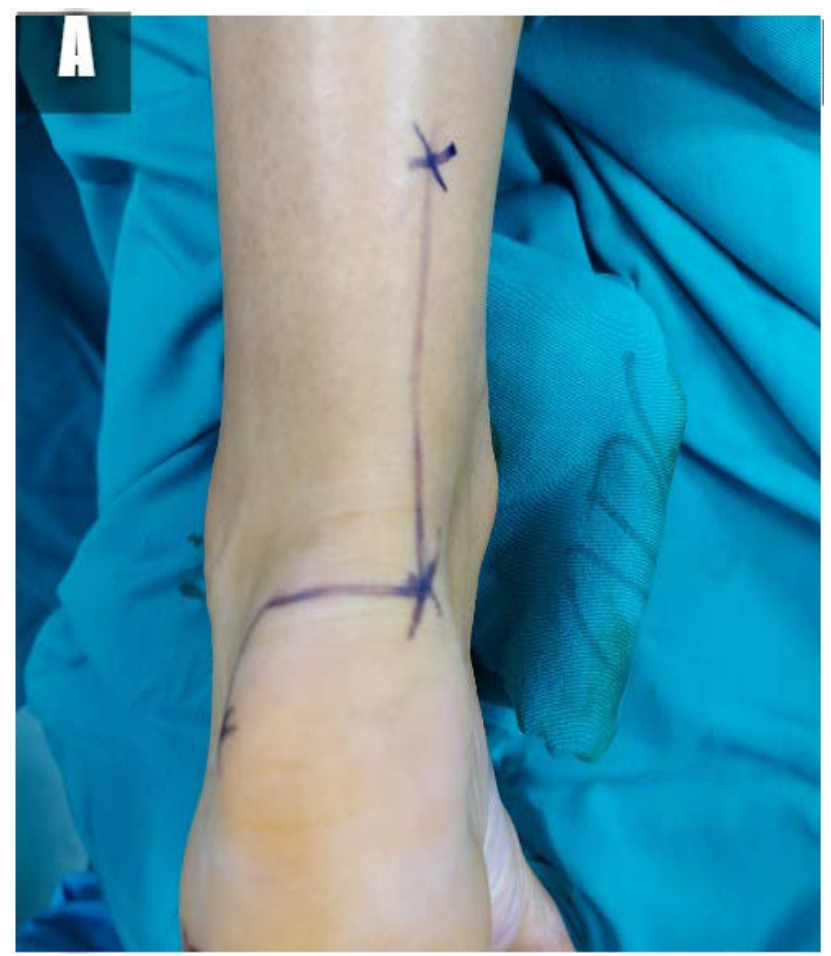


tion along with signs of significant degenerative changes.

Since nonoperative treatment was not successful, a decision was made to perform surgery, with the idea of performing a resection of the degenerated and injured part of the tendon and strengthening it with an FHL tendon transfer. Placed in the pronation position, under regional anaesthesia and with the use of the tourniquet, the tendon was approached medially through the Hockey stick incision (Figure 1A). A careful, longitudinal incision of the paratenon was executed. The scarred and deformed posterior distal part of the tendon at the level of the insertion was removed in whole and involved more than $50 \%$ of the tendon circumference (Figure $1 \mathrm{~B}$ and $\mathrm{C}$ ). The FHL tendon was then dissected through the same incision (Figure 2A). Upon cutting the deep fascia, the muscle belly and the muscle-tendon junction were identified. A second incision was performed at the level of the knot of Henry to approach the distal part of the tendon (Figure 2B). Upon identification of the tendon, a disinsertion was performed as distally as possible to receive the maximum length of the tendon body. The distal end of the FHL was sutured to the FDL tendon and the proximal end of the FHL was moved to the level of the first incision. A $4 \mathrm{~mm}$ tunnel was then drilled through the mediolateral part of the calcaneus tuberosity. The tendon was passed through the tunnel and around the Achilles tendon,

Figure 1. B: Distal part of the Achilles tendon after removal of scarred tisscue

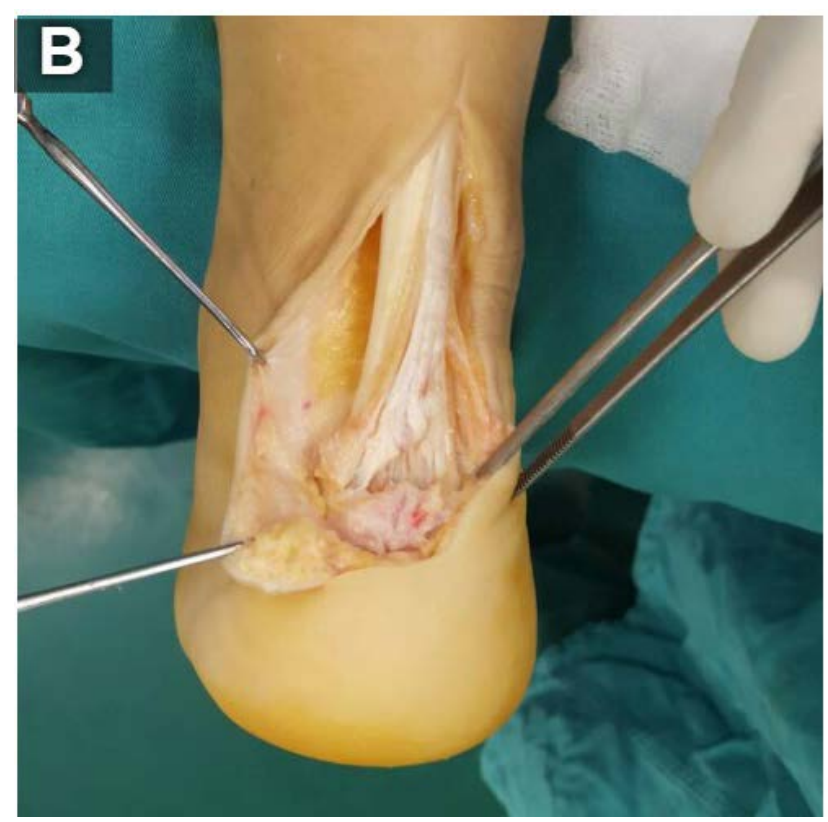

to which it was sutured in the shape of the letter $\mathrm{U}$ using Ticron 2.0 (Figure 2C and Figure 3). Postoperatively, a plaster immobilization reaching above the knee with the foot in physiological equinus was placed and worn for two weeks. A functional lower leg orthosis with a $2 \mathrm{~cm}$ elevation was then placed and worn for another 2 weeks. The patient was then allowed to stand on the injured leg and physical therapy was required in the form of passive flexion

Figure 1. C: Scarred tissue from the distal part of the Achilles tendon

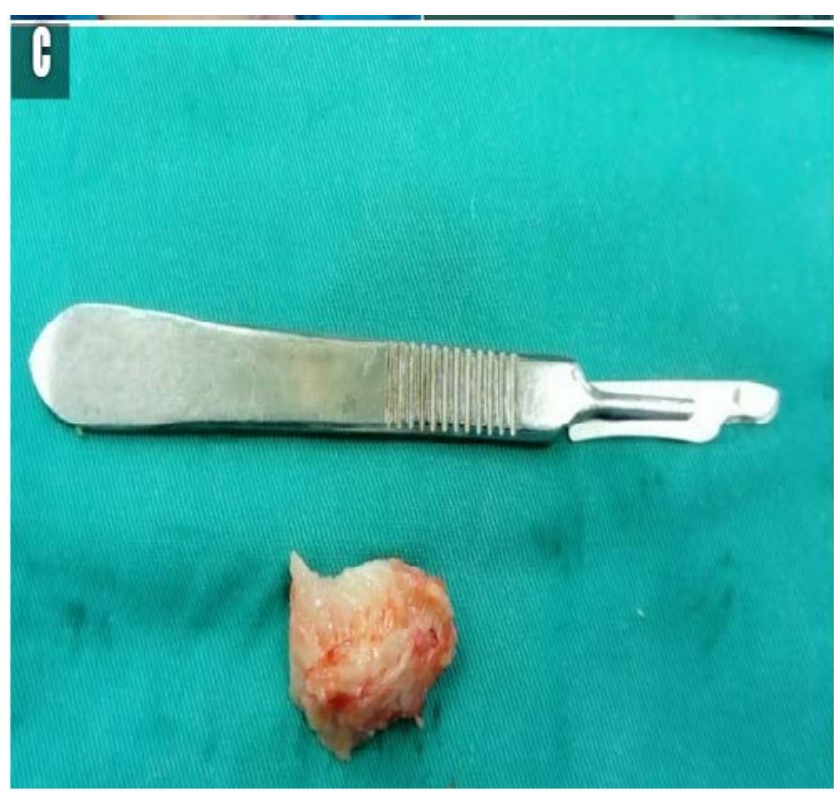

Figure 2. A: FHL tendon dissected through the same incision

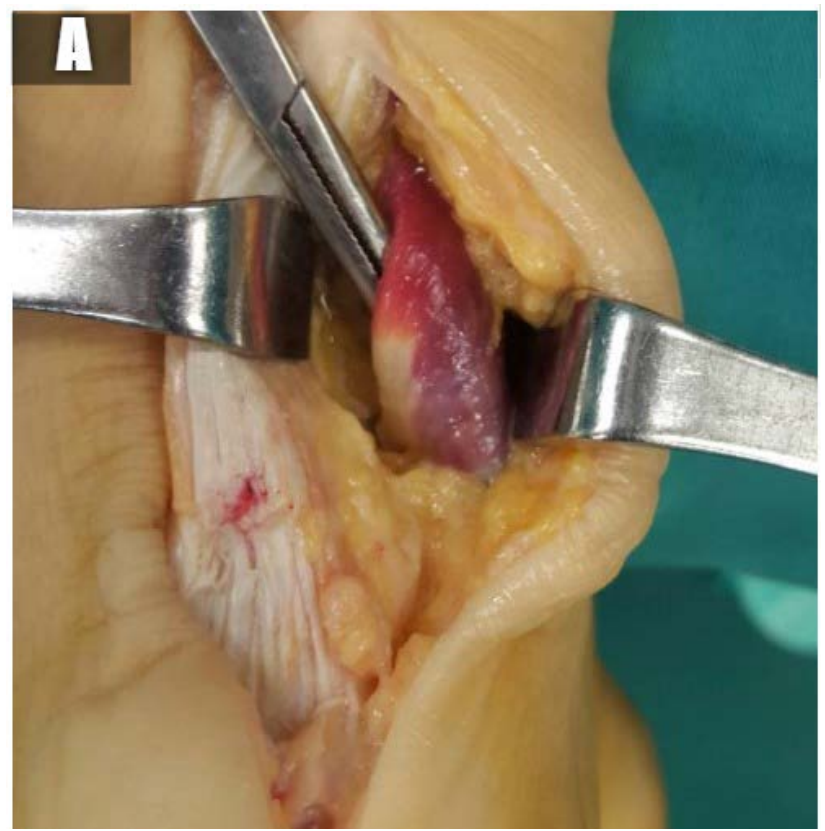


Figure 2. B: The second incision was performed at the level of the knot of Henry to approach the distal part of the FHL tendon

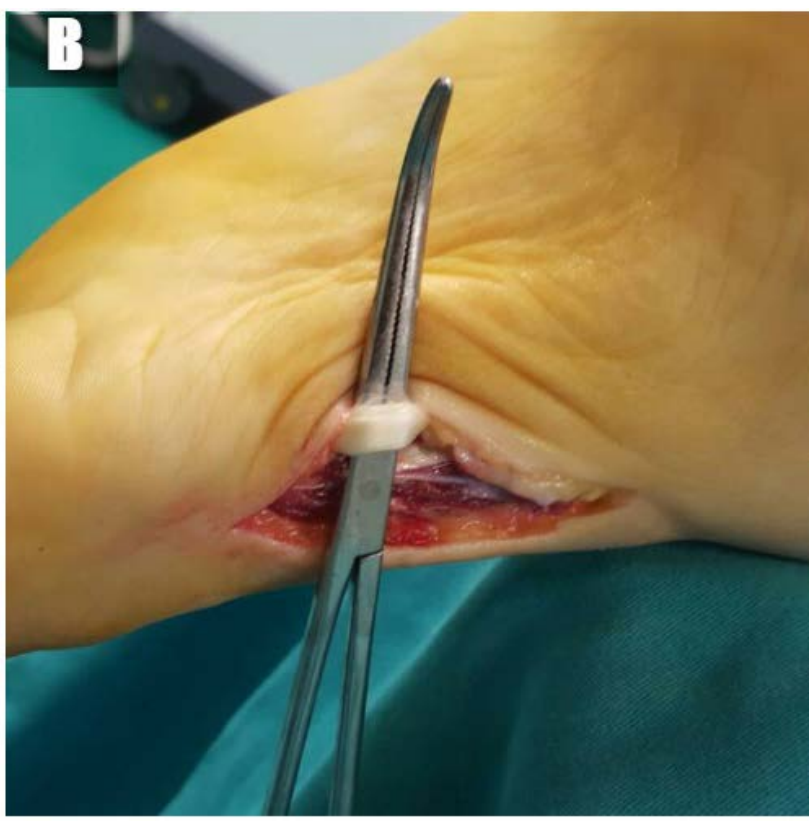

Figure 2. C: Full length of the FHL tendon

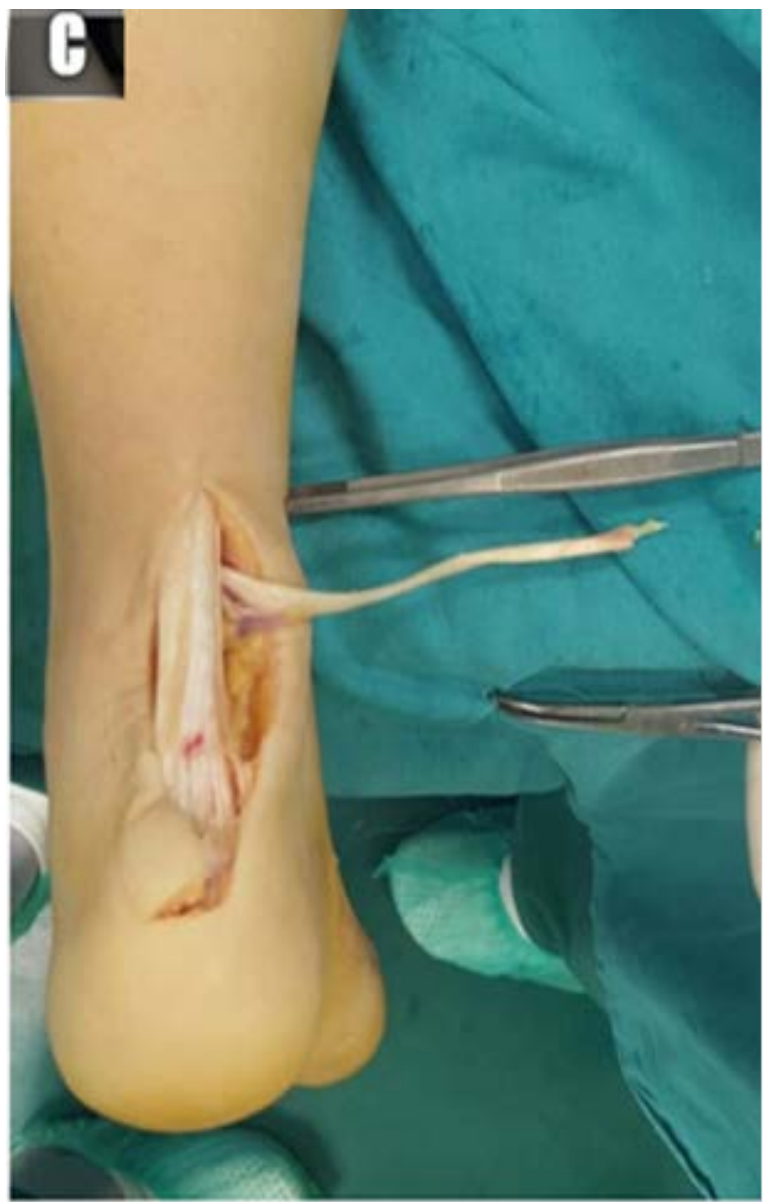

Figure 3. Suture of the FHL tendon around the Achilles tendon in the shape of the letter $U$

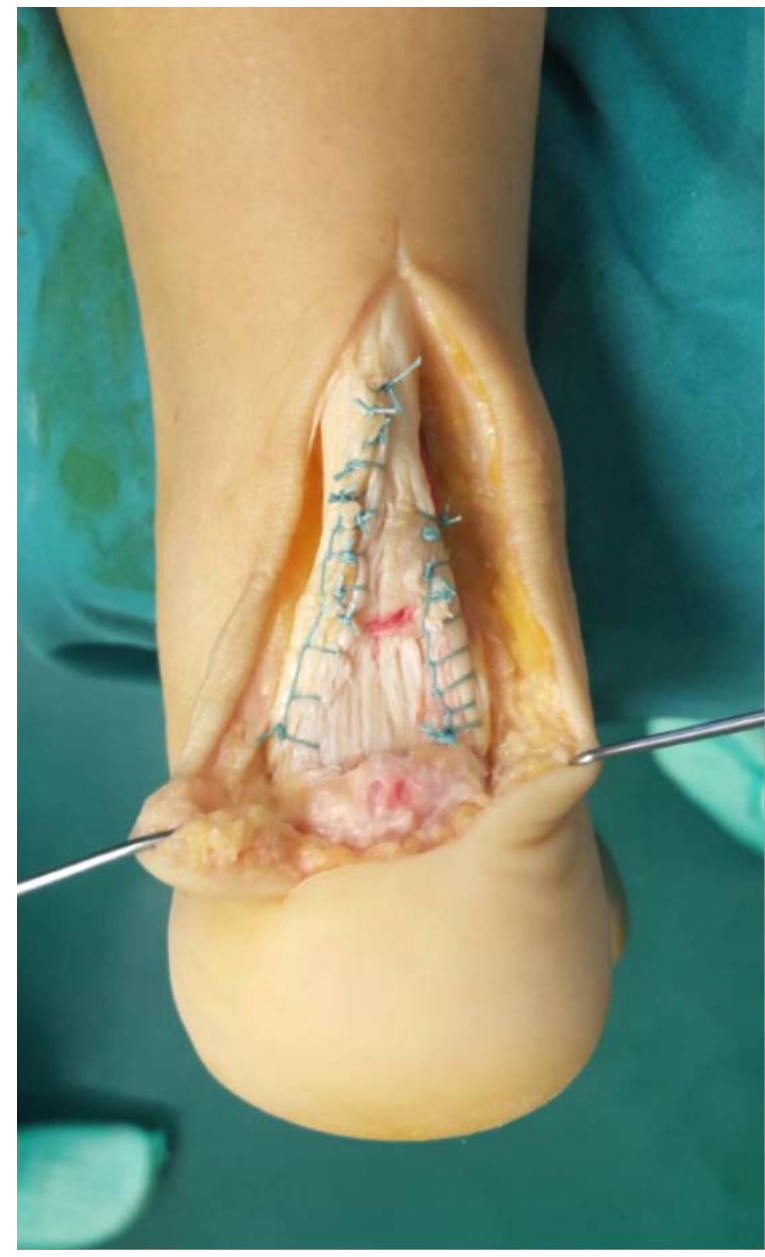

and extension to be performed beneath the level of pain for 4 weeks. After that, the orthosis was gradually removed and the patient was allowed to transfer his full body weight on the injured leg, to wear regular shoes while continuing with physical therapy. Three months after surgery, he was allowed to gradually return to his normal physical activity, training and jogging. Six months after surgery, the patient completely recovered and returned to normal physical activity and handball training.

\section{SECOND CASE REPORT}

The second patient was a 48-year-old woman complaining of constant pain, edema and discomfort in the left Achilles tendon region for the last seven months. She had had an injury, described as a sudden onset of sharp pain, while fast walking, which was her regular form of exercise several times a week. A nonoperative form of treatment was initi- 
ated, consisting of rest, analgesic and anti-edema ointment application and an orthosis placement. Apart from physical examination and an X-ray, no other diagnostic procedure was performed at the time. As the symptoms partially receded, she was ordered to commence physical therapy, during which her symptoms worsened and she had to stop. An MRI scan showed, as in the first case presented, a partial rupture at the level of the distal insertion of the Achilles tendon, along with signs of significant degenerative changes spanning the complete circumference of the most distal $3-4 \mathrm{~cm}$ of the tendon. A decision was made to perform surgery to operatively remove the degenerated and scarred tissue while strengthening the Achilles tendon with an FHL tendon transfer. The operative procedure and postoperative recovery went exactly as previously described in the first case presented. Six months after the operation, the patient was able to return completely to her usual physical activities and recreational fast walking.

Both presented patients belong to the highrisk group for Achilles tendon injury: active athlete and the middle-aged person practicing recreational sports. Both patients were tested using AOFS and ATRS tests preoperatively. The uninjured leg was also tested, under the presumption that the state of the uninjured leg is similar to the state of the injured leg before injury.

In the first patient, the AOFS score on the injured leg was 53 with 95 on the healthy leg preoperatively. Postoperatively, it was 95 on the injured

Figure 4. A: Full plantar flexion one eyar after surgery

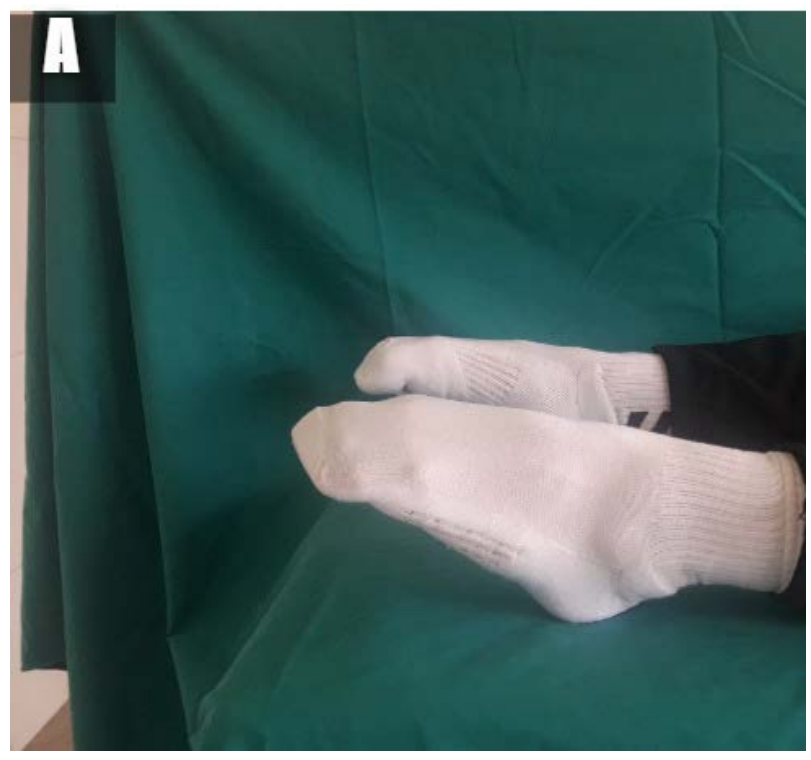

leg. The ATRS score was measured at 37 preoperatively and 92 postoperatively.

The second patient's AOFAS score was 61 on the injured leg and 95 on the healthy leg preoperatively and 85 on the injured leg postoperatively. The ATRS score was 35 preoperatively and 88 postoperatively.

Figure 4. B: Full dorsiflexion one year after surgery

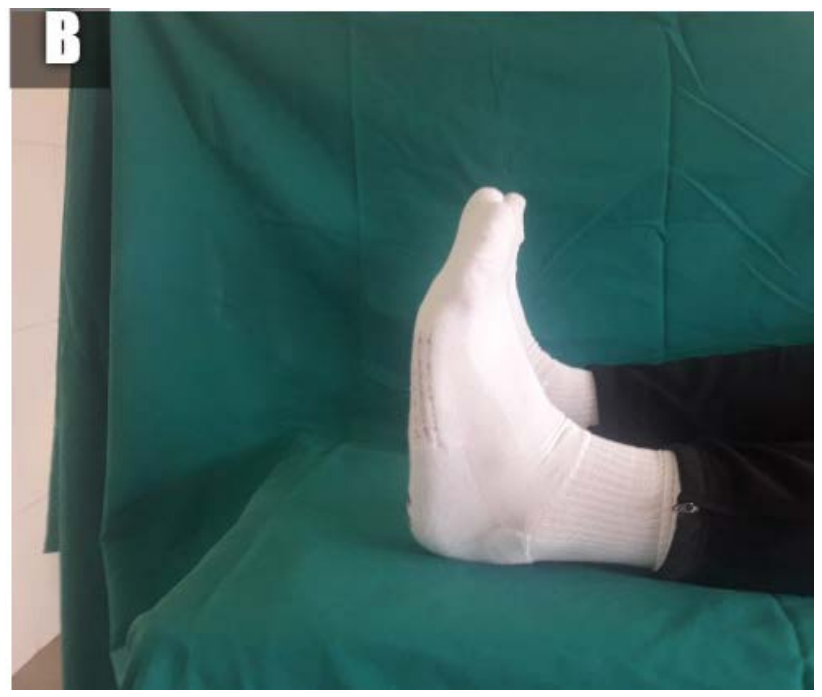

Figure 4. C: Tiptoe standing on one leg one year after surgery

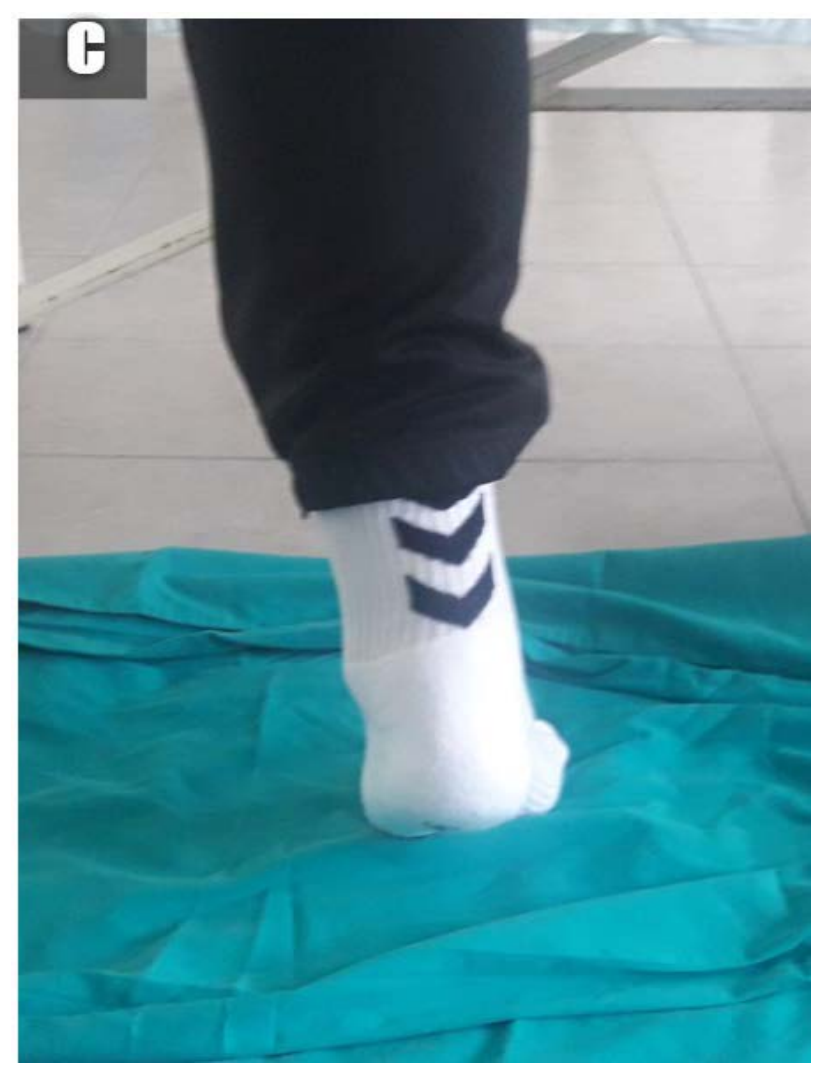


Control testing was performed a year after the operation. Both patients had full flexion and extension in the ankle, symmetrical to the healthy foot (Figure 4A and B). Both patients could stand on their tiptoes longer than 15 seconds (Figure 4C). There was no active big toe flexion, but there was also no hyperextension. Both patients denied having problems due to lack of big toe flexion during sports activities and everyday life. There were no other complications.

\section{DISCUSSION}

While there are differences in opinion when it comes to treating acute ruptures and diseases of the Achilles tendon, chronic ruptures and diseases are almost always treated surgically. Injury and disease of the Achilles tendon are most commonly present in professional and recreational athletes, which was the case with our presented patients as well. Chronic disease causes significant disability and limits life and sports activities. Aside from the clear mechanism of injury, which the patient usually mentions as soon as they present, during further examination (ultrasound, MRI, surgery) an underlying degenerative process is a very common finding. Partial or total ruptures, as well as degenerative changes, are most commonly localized in the distal part of the tendon, 2 to $6 \mathrm{~cm}$ proximal to the insertion $(11,12)$. Doppler sonography shows that the posterior distal part of the tendon has the poorest vascularization $(13,14)$. The presented patients had scar tissue removed precisely in that zone. The MRI, as well as intraoperative findings, showed that degenerative changes encompassed almost the entire circumference of the tendon in both our patients.

Various operative procedures are used to treat chronic lesions, from the use of autografts, FHL, FDL, PB and hamstrings transposition to allografts and synthetic grafts. The FHL transposition was first executed by Hansen in 1991 (15). Since then, many papers were published confirming the reliability and advantage of this technique. FHL is, aside from the triceps surae, the strongest plantar flexor in the ankle joint (16). Its line of contraction is most similar to the
Achilles tendon. Both are activated at the same time during the stance phase of the gait. Therefore, it is not necessary to re-educate the tendon postoperatively. The FHL tendon is also anatomically very close to the Achilles tendon and can be approached and dissected through the same incision. The FHL transposition also provides the of plantar flexion strength reinforcement, which is commonly compromised when fascial advancement is the only procedure performed. The vascularization of the Achilles tendon, benefits as well as the muscle belly of the FHL is extended distally into the avascular zone of the Achilles tendon, which contributes to the additional blood supply to the repaired part of the tendon. Besides that, the normal muscle balance of the ankle is maintained, since a muscle with the same function is being transferred, which is not the case with PB transposition. Passing the tendon through the tunnel in the heel bone enables excellent fixation, which makes early mobilization, early body weight support and passive exercise possible (17).

As a result of all aspects mentioned, good outcomes were recorded in our patients, which is in line with the papers of other authors, Hartog and Wegrzyn and Yeoman et al $(18,19)$. Our patients had a significant rise in the AOFAS and ATRS scores and a good result that enabled them to return fully to their usual physical activity. The loss of big toe flexion, which is the result of the transposition, has proven to be insignificant when it came to the patients' everyday activities, as described by our patients and by other authors. It is assumed that the suturing of the distal end of the FHL tendon to the FDL tendon serves to minimize the negative effects of the transposition (20).

\section{CONCLUSION}

Chronic disease and injury of the Achilles tendon are common conditions that often significantly diminish the work and life force of a patient. Surgery is necessary and serves to enable the patients to return to their usual activities and life habits as much as possible. Our little series has just proven that. 


\section{References}

1. Maffulli N. Rupture of the Achilles tendon. J Bone Joint Surg Am 1999;81:1019-36

https://doi.org/10.2106/00004623-199907000-00017

2. Moller A, Astron $M$, Westlin $N$. Increasing incidence of Achilles tendon rupture. Acta Orthop Scand1996;67(5):479-81. https://doi.org/10.3109/17453679608996672

3. Landvater SJ, Renstrom PA. Complete Achilles tendon ruptures. Clin Sports Med 1992; 11(4):741-58

4. Carlstedt CA. Mechanical and chemical factors in tendon healing: effect of indomethacin and surgery in the rabbit. Acta Orthop Scand 1987;(Suppl 224) https://doi.org/10.3109/17453678709154163

5. Williams JG. Achilles tendon lesions in sport. Sports Med 1986;3(2):114-35

https://doi.org/10.2165/00007256-198603020-00003

6. Astrom, M. On the nature and etiology of chronic Achilles tendinopathy. Lund University, Sweden; 1997;1-110

7. Farizon F, Pages A, Azoulai JJ, de Lavison R, Bousquet G. Surgical treatment of ruptures of the Achilles tendon. a propos of 42 cases treated by Bosworth's technique. Rev Chir Orthop Reparatrice de l'Appareil Moteur1997;83(1):65-9

8. Abraham E, Pankovich AM. Neglected rupture of the Achilles tendon: treatment by V-Y tendinous flap. J Bone Joint Surg Am 1975;57:253-5. https://doi.org/10.2106/00004623-197557020-00019

9. Athar Ahemad MA, Abdul NM, Syed MA. Chronic insertional achilles tendon ruptures treated by suture anchor repair and augmentation with flexor hallucis longus tendon transfer. Int J Res Orthop2018;4(2):227-31 https://doi.org/10.18203/issn.24554510.Int/ResOrthop20180442

10. Kitaoka HB, Alexander IJ, Adelaar RS, at al Clinical rating systems for the ankle, hindfoot, midfoot, hallux and lessertoes. Foot Ankle 1994;15:349-53.

https://doi.org/10.1177/107110079401500701

11. Perry J. Achilles tendon anatomy. Foot and Ankle Clinics 1997;2:363-70.

12. Astrom M. On the nature and etiology of chronic achilles tendinopathy.PhD thesis, Lund University, Sweden, 1997

13. Astrom M, Westlin N. Blood flow in the human Achilles tendon assessed by laser Doppler flowmetry. J Orthop Res 1994;12(2):246-52. https://doi.org/10.1002/jor.1100120214

14. Zantop T, Tillmann B, Petersen W. Quantitative assessment of blood vessels of the human Achilles tendon: an immunohistochemical cadaver study. Arch Orthop Trauma Surg 2003;123(9):501-4. https://doi.org/10.1007/s00402-003-0491-2

15. Hansen ST. Trauma to the heel cord. In: Jahss MH,ed. Disorders of the foot and ankle, $2^{\text {nd }}$ edn. W.B.Saunders, Philadelphia, 1991: 2357.

16. Silver RL, dela Garza J, Rang M. The myth of muscle balance. A study of relative strengths and excursions of normal muscles about the foot and ankle. J Bone Joint Surg Br 1985;67:432-7. https://doi.org/10.1302/0301-620X.67B3.3997956

17. El-Tantawy A, Azzam W. FHL tendon transfer in the reconstruction of extensive insertional Achilles tendinopathy in elderly: an improved technique. Eur J Orthop Surg Traumatol 2015;25;583-90 https://doi.org/10.1007/s00590-014-1569-y

18. Wegrzyn J, Luciani JF, Phillipot R, at al. Chronic Achilles Tendon rupture reconstruction using a modified flexor hallucis longus transfer. Int Orthop 2010;34:1187-92. https://doi.org/10.1007/s00264-009-0859-1

19. Yeoman T, Brown MJC, Pillai A. Earlypostoperative results of neglected tendo- 
Achilles rupture reconstruction using short flexor hallucislongus tendon transfer: A prospective review. The Foot 2012;22:219-23.

https://doi.org/10.1016/j.foot.2012.05.004
20. Hahn F, Maiwald C, Horstmann T, Vienne P. Changes in plantar pressure distribution after Achilles tendon augmentation with flexor hallucis longus transfer. Clin Biomech 2008;23(1):109-16. https://doi.org/10.1016/j.clinbiomech.2007.08.015

\title{
Hronična parcijalna ruptura Ahilove tetive - transfer tetive flexor hallucis longus: prikaz dva slučaja
}

\author{
Mihajlo Mitrović1, Dražen Jelača', Ivana Mitrović \\ ${ }^{1}$ Opšta bolnica Pančevo, Pančevo, Srbija \\ ${ }^{2}$ Gradski zavod za hitnu medicinsku pomoć, Beograd, Srbija
}

\section{SAŽETAK}

Povrede Ahilove tetive karakteristične su za aktivne sportiste, ali i za rekreativce srednjih godina. Etiologija povreda i oboljenja nije u potpunosti poznata. Pored jasnog traumatskog mehanizma, kao uzročnika akutne rupture, istraživanja su pokazala da u osnovi rupture postoje hronične degenerativne promene. Dok kod akutnih ruptura i dalje postoje dileme oko načina lečenja, hronične rupture i oboljenja dominatno se leče operativno. Brojne su operativne procedure koje se preduzimaju, od ekcizije izmenjenih, degenerativnih promena i dekompresije tetive, preko rekonstrukcije tkivom fascijom latom i VY plastikom, do transfera tetiva (flexor hallucis longus - FHL, flexor digitorum tongus - FDL, peroneus borevis - PB) i primene alograftova $\mathrm{i}$ sintetskih grafotova. Cilj našeg rada je da prikažemo rezultate lečenja hronične parcijalne rupture Ahilove tetive ekcizijom ožiljnog tkiva i njenim ojačavanjem transpozicijom tetive FHL. Proceduru smo primenili kod aktivnog sportiste i kod rekreativca, koji su prethodno duže vreme lečeni neoperativno. Preoperativno i postoperativno testirani su AOFAS i ATRS testovima. Rezultati su pokazali značajno poboljšanje funkcije i potpuno vraćanje bolesnika uobičajenim životnim aktivnostima. Postoperativni rezultati AOFAS i ATRS skora bili su približno identični rezultatima nepovređenih tetiva. Kroz brojne radove $\mathbf{i}$ našu malu seriju, pokazalo se da je primena transpozicije tetive FHL $u$ lečenju hroničnih povreda i oboljenja Ahilove tetive sigurna i efiksana metoda.

Ključne reči: Ahilova tetiva, tetiva flexor hallucis longus, transpozicija, parcijalna ruptura 